\title{
Optimization of a suite of flathead catfish (Pylodictis olivaris) microsatellite markers for understanding the population genetics of introduced populations in the northeast United States
}

\author{
Shannon L. White ${ }^{*} \mathbb{C}$, Michael S. Eackles ${ }^{2}$, Tyler Wagner ${ }^{3}$, Megan Schall ${ }^{4}$, Geoff Smith ${ }^{5}$, Julian Avery ${ }^{6}$ and
} David C. Kazyak²

\begin{abstract}
Objective: Flathead catfish are rapidly expanding into nonnative waterways throughout the United States. Once established, flathead catfish may cause disruptions to the local ecosystem through consumption and competition with native fishes, including species of conservation concern. Flathead catfish often become a popular sport fish in their introduced range, and so management strategies must frequently balance the need to protect native and naturalized fauna while meeting the desire to maintain or enhance fisheries. However, there are currently few tools available to inform management of invasive flathead catfish (Pylodictis olivaris). We describe a suite of microsatellite loci that can be used to characterize population structure, predict invasion history, and assess potential mitigation strategies for flathead catfish.
\end{abstract}

Results: Our panel of 13 microsatellite loci were polymorphic and appear to be informative for population genetic studies of flathead catfish. We found moderate levels of diversity in four nonnative collections of flathead catfish in the Pennsylvania and Maryland sections of the Susquehanna River and the Schuylkill River, Pennsylvania. Analyses suggested patterns of genetic differentiation within- and among-rivers, highlighting the utility of this marker panel for understanding the structure and assessing the degree of connectivity among flathead catfish populations.

Keywords: Microsatellites, Flathead catfish Pylodictis olivaris, Population genetics

\section{Introduction}

Flathead catfish (Pylodictis olivaris) is a large piscivorous catfish native to the Mississippi, Mobile, and Rio Grande basins in the United States that has experienced rapid range expansions following permitted and non-permitted stocking [1]. Once introduced, there are relatively few

\footnotetext{
*Correspondence: slwhite@contractor.usgs.gov

${ }^{1}$ Natural Systems Analysts, Inc. Under Contract to the U.S. Geological Survey, Eastern Ecological Science Center, Kearneysville, WV 25430, USA Full list of author information is available at the end of the article
}

environmental or intrinsic constraints to dispersal and the species typically experiences high invasion success owing to its long lifespan, fast growth, early maturation, high fecundity, high salinity tolerance, and lack of natural predators [2, 3]. Negative effects of introduced flathead catfish on migratory and resident fishes, including threatened and endangered species, are well-documented [4-6], and models suggest that predation and competition by flathead catfish suppress native fish biomass as much as 50\% [7]. Together, high propagule pressure and 
interactions with native fauna make flathead catfish one of the most harmful of all introduced fishes in the United States [8].

Although introduced flathead catfish populations can have substantial deleterious effects on native biota, popular recreational fisheries have developed wherever they have been introduced. Given the prolific nature of the species, popularity of the fishery, and angler behavior (e.g., catch-and-release fishing), eradication of nonnative flathead catfish may not be feasible or warranted for many populations [9]. There are few resources available to assist in the development of flathead catfish management strategies, and tools are needed to help limit flathead interactions with native and naturalized fish populations while recognizing the growing popularity of the recreational fisheries that have resulted from their introduction. In particular, understanding population genetic structure may improve management outcomes by providing insights into demographic and evolutionary trajectories, spatial scales of metapopulation connectivity, as well as historical and future invasion pathways. Ultimately, this can help identify the most efficacious conservation strategies to use in flathead catfish management, both within the focal areas and in other watersheds which may be facing future invasions.

Here, we describe a panel of microsatellite loci that can be used to support management of flathead catfish populations through studies of population genetics. We highlight the utility of this marker panel in a population genetic analysis of flathead catfish collected from two river basins (Delaware and Susquehanna rivers) within its introduced range in Pennsylvania and Maryland.

\section{Main text \\ Methods}

Flathead catfish were collected from one location in the Schuylkill River in the Delaware River Basin in eastern Pennsylvania and three locations distributed along the Susquehanna River in central Pennsylvania and Maryland (Fig. 1a). Fish were collected within a 40-km reach at each sampling location and sampling locations were separated by at least $180 \mathrm{~km}$ of hydrologic distance. An approximately $1 \mathrm{~cm}^{2}$ sample of the caudal fin was collected from each individual, preserved in 95\% ethanol, and provided to the U.S. Geological Survey (USGS) Eastern Ecological Science Center, Kearneysville, WV. All fish sampling and tissue collections were conducted in agreement with the Pennsylvania State University Institutional Animal Care and Use Committee (PROTO201901210).

Microsatellite marker panels have not been previously described for flathead catfish; however, studies have suggested that microsatellites are well-conserved among ictalurid catfishes [10]. Therefore, with the goal of establishing a suite of at least 12 polymorphic loci, we created a list of 25 candidate loci from reviewed literature on channel catfish (Ictalurus punctatus [10-14]). The candidate loci were selected based on the number of alleles observed in channel catfish, allele size, and repeat motif structure. Additionally, some loci had previously been shown to cross amplify in flathead catfish [10]. Flathead

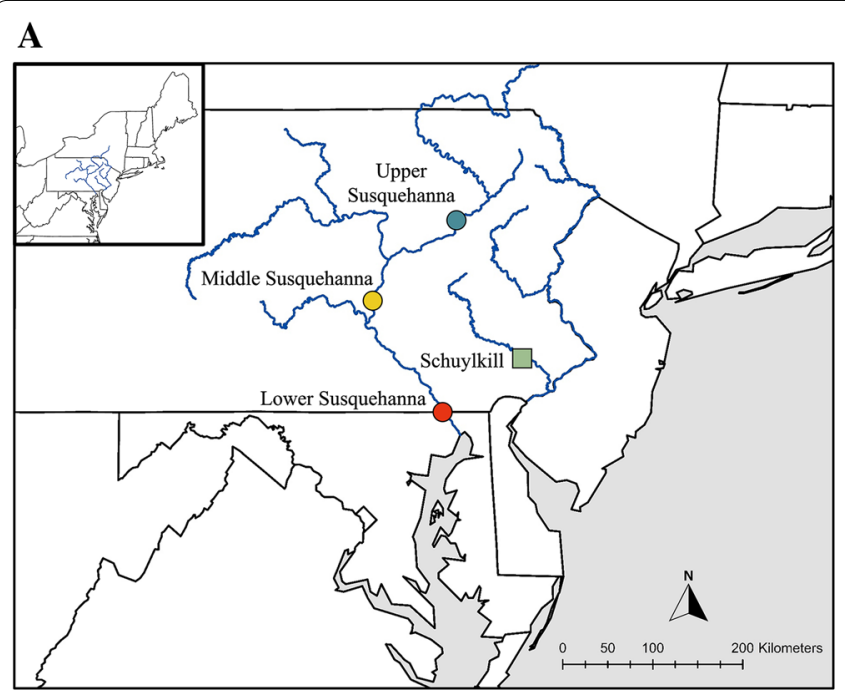

B

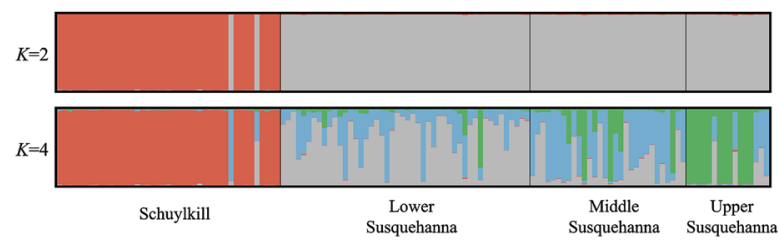

C

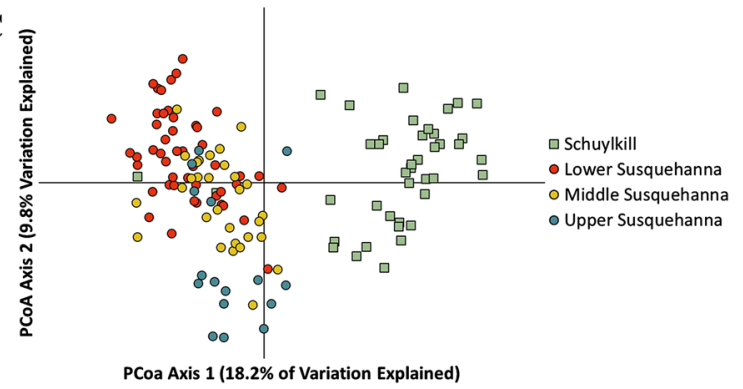

Fig. 1 A Location of flathead catfish (Pylodictis olivaris) samples sites on the Schuylkill and Susquehanna rivers in Pennsylvania and Maryland. B Proportion of individual membership to each of $K=2$ (top) and $K=4$ (bottom) genetic clusters inferred from STRUCTURE analysis for four collections of flathead catfish. C First two dimensions of the principal coordinate analysis (PCoA) for flathead catfish collected from the Schuylkill and Susquehanna rivers. Map produced using ArcGIS 
catfish DNA was isolated from tissue samples using the Qiagen Blood and Tissue extraction kit (Qiagen, Valencia, CA, USA) and screened DNA against the 25 candidate loci. Primers were modified to include a $19 \mathrm{bp}$ M13 tag [15] to the $5^{\prime}$ end of each forward marker to facilitate use of the ABI 3500 capillary electrophoresic Genetic Analyzer. All $15 \mu \mathrm{l}$ PCR reactions were carried out with a third dye-labeled M13 primer complimentary to the tagged forward primer [16].

Of the 25 candidate loci, six loci failed to amplify under varying conditions, including subjection to the $50{ }^{\circ} \mathrm{C}$ to $64{ }^{\circ} \mathrm{C}$ gradient program on a Bio-Rad T100 thermal cycler. Another six loci proved to be monomorphic in the individuals analyzed. The remaining 13 loci that successfully amplified were ultimately chosen for our final panel based on clean amplification, free of artifacts and any co-amplification, number of alleles observed, and annealing temperature compatibility (Table 1). Each of these 13 markers was re-labeled with a fluorescent dye (FAM,
NED, VIC or PET) attached to the $5^{\prime}$ end of the forward primer for detection and fragment length analysis on the ABI 3500 as well as accommodating the multiplexing of multiple loci per reaction. Multiplex configurations were determined with the use of Multiplex Manager 1.0 software [17] resulting in three multiplex reactions or ABI 3500 Genetic Analyzer injections per individual (see Table 1 for details).

Multiplex PCR's were generated on a T100 Thermal Cycler (BIO-RAD) in 96-well semi-skirted plates. Each reaction was $15 \mu \mathrm{l}$ in total volume and contained $1.5 \mu \mathrm{l}$ genomic DNA ( $25 \mathrm{ng} / \mu \mathrm{l}), 4.6 \mu \mathrm{l}$ of nuclease-free water, $7.5 \mu$ l Qiagen Multiplex 1X MasterMix, 0.2-0.5 $\mu$ l of each primer (see Table 1 for final concentration for each pair of primers). Cycling conditions included an initial activation and denaturing step of $95^{\circ} \mathrm{C}$ for 15 min followed by 34 cycles of $94{ }^{\circ} \mathrm{C}$ denaturation for $30 \mathrm{~s}, 55^{\circ} \mathrm{C}$ to $58{ }^{\circ} \mathrm{C}$ annealing for $90 \mathrm{~s}\left(\mathrm{MP}-1\right.$ at $58{ }^{\circ} \mathrm{C}, \mathrm{MP}-2$ at $55^{\circ} \mathrm{C}$ and

Table 1 Characteristics of 13 microsatellite loci tested for genetic analyses of flathead catfish (Pylodictis olivaris)

\begin{tabular}{|c|c|c|c|c|c|c|c|}
\hline Locus & Primer Sequences $5^{\prime}-3^{\prime}$ & $\begin{array}{l}\text { Multiplex } \\
\text { mix }\end{array}$ & Fluorescent dye & $\mu \mathrm{M}$ & Size range (bp) & Repeat motif & Source \\
\hline \multirow[t]{2}{*}{ GY113J02 } & F: CACGTTCAGGCCAATACAACAC & B & 6-FAM & 0.3 & $370-400$ & $\operatorname{AAT}_{(17)}$ & [11] \\
\hline & R: GTTTGTCCACTACCTTGTGCCC & & & & & & \\
\hline \multirow[t]{2}{*}{ GY047K03 } & F: CCCTCTATGCCTGTGATTGTTTATG & B & 6-FAM & 0.2 & $190-230$ & Not available & [11] \\
\hline & R: GTTTGTCCACCAAGTCCCTGTGTAAC & & & & & & \\
\hline \multirow[t]{2}{*}{ IpCG0071 } & F: CGAAGGTTTATAACTAAGGAGCAGG & B & VIC & 0.1 & $145-190$ & $\operatorname{AGAT}_{(11)} \mathrm{GGAT}_{(3)} \mathrm{AGAT}_{(2)}$ & [11] \\
\hline & R: GTTTGTACCTGGCTGTGAAGACAC & & & & & $\left.\left.{ }_{(3)}\right]_{4}\right]_{(6)}\left[A G A T_{(1)} G G A T\right.$ & \\
\hline \multirow[t]{2}{*}{$71-75$} & F: CGCTAAATGATCCATTCCACC & C & PET & 0.2 & $110-160$ & $\mathrm{CA}_{(12)}$ & [11] \\
\hline & R: GTTTCAGTGCCGCCATTCTCAC & & & & & & \\
\hline \multirow[t]{2}{*}{ Ip077 } & F: GAAACACAATGTACAGTAAGCTG & C & 6-FAM & 0.2 & $110-150$ & GT & [14] \\
\hline & R: GCTGCTTCTTATGGAATCTC & & & & & & \\
\hline \multirow[t]{2}{*}{ IpCG00189 } & F: GATCCTGTGCTAAAGAAACCAAG & $A$ & VIC & 0.1 & $200-300$ & AAT & {$[12,13]$} \\
\hline & R: GTGCCGCAGTGTGTTGTAAA & & & & & & \\
\hline \multirow[t]{2}{*}{ 1p271 } & F:TGGGGAAAAAGAAAGTAATAACG & $A$ & 6-FAM & 0.2 & $155-185$ & $\mathrm{TG}_{(18)} \mathrm{GA}_{(19)}$ & [10] \\
\hline & R: CAGTAGAGCTTTGAAGCCATTC & & & & & & \\
\hline \multirow[t]{2}{*}{ 1p357 } & F: CCTGCCACCATATCAGTGAATTT & A & NED & 0.2 & $100-160$ & $\mathrm{CA}_{(18)}$ & [10] \\
\hline & R: GATAATGAGTCTCCGGAGGTGC & & & & & & \\
\hline \multirow[t]{2}{*}{ Ip365 } & F:TAAAGGATCTGATTCACCGTATC & B & PET & 0.3 & $100-145$ & $\mathrm{CA}_{(13)}$ & [10] \\
\hline & R: AAACCGCTAACCTACCCTCT & & & & & & \\
\hline \multirow[t]{2}{*}{ Ip372 } & F: GGCACTGAGGTTTGGGCTGCAC & A & PET & 0.3 & $190-220$ & $\mathrm{CA}_{(8)}$ & [10] \\
\hline & R:TGGCATCGCTCCTCATCATCCTG & & & & & & \\
\hline \multirow[t]{2}{*}{ Ip554 } & F: GAGATGAAGTGAGATGAAGACAG & A & NED & 0.2 & $220-255$ & $\mathrm{GA}_{(20)}$ & [10] \\
\hline & R:TGCTTAAATAATGACACGGTTC & & & & & & \\
\hline \multirow[t]{2}{*}{ Ip591 } & F: CTGCTTTAGGTCCACCCACTGC & C & NED & 0.2 & $130-180$ & $\mathrm{GT}, \mathrm{GA}$ & [14] \\
\hline & R: AGGCACTTGACATTTAGCCTGC & & & & & & \\
\hline \multirow[t]{2}{*}{ IpCG0001 } & F: GTACCACTGGTCAGTATCTCC & C & VIC & 0.1 & $175-215$ & $\mathrm{AAT}_{(20)}$ & [11] \\
\hline & R: GTTTCACCATCACCAGAGTCCAGG & & & & & & \\
\hline
\end{tabular}

F Forward primer, $R$ : reverse primer, Multiplex Mix assignment of each locus to one of three PCR reactions, Fluorescent Dye dye used for each locus within each PCR reaction, $\mu M$ primer concentration used in the PCR reaction, Size Range (bp) bp size of the alleles genotyped, Repeat Motif motif and number of repeats (in parentheses) for each locus, Source citation for the locus 
MP-3 at $\left.56{ }^{\circ} \mathrm{C}\right), 72{ }^{\circ} \mathrm{C}$ extension step for $60 \mathrm{~s}$ and a final extension of $60{ }^{\circ} \mathrm{C}$ for $60 \mathrm{~s}$. Upon cycling completion and cooling, $1 \mu \mathrm{l}$ of each reaction was removed and added to $40 \mu \mathrm{l}$ of nuclease-free water. From this dilution, $1.5 \mu \mathrm{l}$ was added to $12 \mu \mathrm{l}$ ultra-grade formamide and $0.2 \mu \mathrm{l}$ of GeneScan 500 LIZ size standard. This mixture was briefly centrifuged to remove any bubbles that would impede capillary electrophoresis and then denatured for $5 \mathrm{~min}$ at $95{ }^{\circ} \mathrm{C}$, cooled for $5 \mathrm{~min}$ then loaded on an 8-capillary ABI-3500 for fragment length analysis. Allele calling and binning was performed with GeneMapper 4.0 software (Applied Biosystems).

\section{Data analysis}

Final testing of the microsatellite locus panel included $n=43$ individuals from the Schuylkill River, and $n=48$, 30, 16 individuals from the lower, middle, and upper Susquehanna River, respectively. Genotypic data were analyzed in MICRO-CHECKER v 2.2.3 [18] to assess the occurrence of null alleles, large allele dropout, and scoring errors.

We used R package GENEPOP [19] to perform exact tests to determine if the distribution of genotypes at each locus conformed to Hardy-Weinberg equilibrium (HWE) and test for linkage disequilibrium (LD). Significance levels for HWE and LD tests were adjusted using the sequential Bonferroni correction. We used GenAlEx $[20,21]$ to estimate allelic richness $\left(A_{R}\right)$, observed $\left(H_{O}\right)$ and unbiased expected $\left(u H_{E}\right)$ heterozygosity, the number of private alleles $(P)$, and the fixation index $(F)$ and the program HP-Rare [22] to estimate rarefied allelic richness $\left(r A_{R}\right.$; standardized to 40 alleles) for each collection. We also used GenAlEx to perform an analysis of molecular variance (AMOVA) to understand the spatial scale of genetic variation within and between river basins.

To evaluate the extent of genetic differentiation among collections, we calculated pairwise $F_{S T}^{\prime}$ in GenAlEx. We also used the Bayesian clustering program STRUCTU $\mathrm{RE} \mathrm{v}$ 2.3.4 [23] to identify population structure among the four collections. We ran 10 independent STRUCTU RE runs for each of $K=1$ to 5 genetic clusters using the admixture model with no a priori information on sample location. Each STRUCTURE run had 200,000 iterations as burn-in, followed by 100,000 replicates of data collection. Results from STRUCTURE were visualized using STRUCTURESelector [24]. We selected the optimal $K$ value using the $\Delta K$ method [25] but also considered other values of $K$ that showed biologically relevant patterns in genetic structure. We also completed a principal coordinate analysis (PCoA) in GenAlEx to further visualize genetic variation within and among collections.

\section{Results and discussion}

Across all four collections of flathead catfish, we found few deviations from HWE or LD, no scoring errors, and no evidence of large allele dropout. However, there was possible evidence of null alleles at two loci (IpCG00189 and Ip271). All 13 loci were polymorphic across the four collections $\left(A_{R}\right.$ per locus range $=2$ to 6$)$ and heterozygosity and allelic richness were moderate in each collection (Table 2). No private alleles were detected in the middle or lower Susquehanna, but we note a larger number of private alleles in the Schuylkill $(n=17)$ relative to those observed in the upper Susquehanna $(n=2)$ collection.

All pairwise $F_{S T}^{\prime}$ values were statistically significant $(P<0.001)$, with the largest values observed between the collection site on the Schuylkill and all the sites on the Susquehanna River (Table 2). The STRUCTU $\mathrm{RE}$ analysis showed the most support for $K=2$ genetic clusters, which generally corresponded to fish collected in the Schuylkill and Susquehanna rivers. However, two individuals captured in the Schuylkill assigned most closely to the Susquehanna cluster. We also evaluated patterns of differentiation at $K=4$

Table 2 Population genetics summary for four collections of flathead catfish (Pylodictis olivaris)

\begin{tabular}{|c|c|c|c|c|c|c|c|c|c|c|c|c|}
\hline Site & $N$ & $A_{R}$ & $r A_{R}$ & $H_{O}$ & $H_{E}$ & $u H_{E}$ & $F$ & $P$ & $\%$ Poly Loci & $\begin{array}{l}\text { HW \# Sig } \\
\text { Loci }\end{array}$ & $\begin{array}{l}\text { LD \# Sig } \\
\text { Pairs }\end{array}$ & $\begin{array}{l}\text { Average } \\
\text { Pairwise } \\
F_{S T}^{\prime}\end{array}$ \\
\hline Schuylkill & 43 & 3.77 & 3.51 & 0.50 & 0.51 & 0.51 & -0.01 & 17 & $100 \%$ & 1 & 2 & 0.31 \\
\hline Lower Susquehanna & 48 & 2.54 & 2.54 & 0.49 & 0.50 & 0.51 & 0.03 & 0 & $100 \%$ & 1 & 0 & 0.19 \\
\hline Middle Susquehanna & 30 & 2.54 & 2.54 & 0.48 & 0.50 & 0.51 & 0.03 & 0 & $100 \%$ & 0 & 0 & 0.14 \\
\hline Upper Susquehanna & 16 & 2.62 & $2.62^{*}$ & 0.60 & 0.51 & 0.53 & -0.19 & 2 & $100 \%$ & 0 & 0 & 0.20 \\
\hline
\end{tabular}

$N$, sample size; $A_{R^{\prime}}$ allelic richness; $r A_{R^{\prime}}$ rarefied allelic richness (standardized to 40 alleles); $H_{O}$, observed heterozygosity; $H_{E \prime}$ expected heterozygosity; $u H_{E,}$ unbiased expected heterozygosity; $F$, fixation index; $P$, number of private alleles; \% Poly Loci, percent of loci that were polymorphic; HW \# Sig Loci, number of loci with significant deviation from HWE; LD \# Sig Pairs, number of loci pairs with significant linkage disequilibrium; Average pairwise $F_{S T}^{\prime}$, average $F_{S T}^{\prime}$ across all pairwise comparisons

* Denotes a rarefied allelic richness value standardized to a larger number of alleles (40) than were sampled in the collection (32) and so the value assumes all alleles were present in the sample 
genetic clusters, which indicated population structure within the Susquehanna River (Fig. 1b). Results of the PCoA supported conclusions generated from STRU CTURE (Fig. 1c). Additionally, results from AMOVA suggested that $13 \%$ of variation was explained by differences between the Schuylkill and Susquehanna basins, with only $5 \%$ and $2 \%$ explained by differences among collections and individuals, respectively. The remaining $80 \%$ of variation was contained within individuals.

Overall, our results highlight the utility of this microsatellite panel for population genetic analysis of flathead catfish. While results should be reviewed with appropriate caution given modest sample sizes, they provide insights into the genetic structure of flathead catfish in Pennsylvania and Maryland. Notably, significant differentiation between collections from the Schuylkill and Susquehanna rivers suggests there may be minimal connectivity between the two rivers, and that the patterns of differentiation may reflect strong founder effects and/or genetically distinct source populations. Strong differentiation between the Schuylkill and Susquehanna rivers is not surprising as these two distinct drainages in the Atlantic Slope are only connected by the C\&D Canal between the Chesapeake and Delaware bays.

We observed less differentiation among collections from the Susquehanna River; however, there did appear to be some spatial clustering. For example, many individuals from the upper Susquehanna strongly assigned to a single genetic cluster, though admixture among all Susquehanna collection locations was apparent. This finding could support hypotheses that flathead catfish in the upper Susquehanna originated from a different source, and that the once disjunct population is now connected to more downstream population(s) through downstream migration and continued upstream invasion.

While additional study is warranted, this analysis adds to the discussion of the invasion history of flathead catfish in Pennsylvania [26, 27], and indicates that there may be multiple introduction pathways, including the potential for on-going human transfer within and between drainages (as evidence by the two individuals collected from the Schuylkill River that were more genetically similar to fish from the Susquehanna River). Though connectivity was apparent, genetic structure within the Susquehanna River suggests that different reaches may be demographically independent, suggesting regional management strategies may be effective in mitigating population growth and spread. Additionally, it may be possible to use genetic tools to model invasion rate in a riverscape genetics framework [28] and monitor human-mitigated spread of flathead catfish.

\section{Limitations}

We surveyed four collections in our analysis, each of which is thought to have been established for less than three decades. Genotyping additional collections, including collections within the species' native range and those with longer residence times will help better characterize allelic patterns at each locus and enable more robust conclusions about the origin of nonnative populations. Further investigation will also help resolve whether the null alleles identified in this study are an artifact of small sample sizes and/or nonrandom sampling.

\section{Abbreviations}

USGS: U.S. Geological Survey; HWE: Hardy-Weinberg equilibrium; LD: Linkage disequilibrium; $A_{R}$ : Allelic richness; $H_{O}$ : Observed heterozygosity; $u H_{E}$ : Unbiased expected heterozygosity; $P$ : Number of private alleles; $F$ : Fixation index; $r A_{R}$. Rarefied allelic richness; PCoA: Principal Coordinates Analysis.

\section{Acknowledgements}

We thank Nick Harris, Sydney Stark, Susquehanna River Basin Commission, Maryland Department of Natural Resources, and Pennsylvania Fish and Boat Commission for assistance in tissue collection and Geoff Waldbieser for comments on a previous draft. Any use of trade, product, or firm names is for descriptive purposes only and does not imply endorsement by the U.S. Government.

\section{Authors' contributions}

All authors contributed to study design and manuscript preparation. SLW and DCK performed data analysis, MSE performed all laboratory analyses, TW procured funds and collected samples, MS, JDA, and GS collected samples and helped identify candidate markers. All authors read and approved the final manuscript.

\section{Funding}

Collections of tissues from the Susquehanna River Basin were done in part using funding provided by Pennsylvania Sea Grant to the Pennsylvania Fish and Boat Commission (5826-COPA-NOAA-0074) and Pennsylvania State University and Federal Aid in Sport Fish Restoration (F-57-R) to the Pennsylvania Fish and Boat Commission.

Availability of data and materials

Microsatellite genotypes are available at USGS ScienceBase (https://doi.org/10. 5066/P98U11RG).

\section{Declarations}

Ethics approval and consent to participate

All procedures and fish handling were conducted in agreement with the Pennsylvania State University Institutional Animal Care and Use Committee (PROTO201901210).

\section{Consent to publish}

Not applicable.

\section{Competing interests}

The authors declare that they have no competing interests.

\section{Author details}

${ }^{1}$ Natural Systems Analysts, Inc. Under Contract to the U.S. Geological Survey, Eastern Ecological Science Center, Kearneysville, WV 25430, USA. ².S. Geological Survey, Eastern Ecological Science Center, Kearneysville, WV 25430, USA. 
${ }^{3}$ U.S. Geological Survey, Pennsylvania Cooperative Fish and Wildlife Research Unit, Pennsylvania State University, University Park, PA 16802, USA. ${ }^{4}$ Biological Sciences, Pennsylvania State University, Hazleton, PA 18202, USA. ${ }^{5}$ Division of Fisheries Management, Pennsylvania Fish and Boat Commission, Bellefonte, PA 16823, USA. ${ }^{6}$ Department of Ecosystem Science and Management, Pennsylvania State University, University Park, PA 16802, USA.

Received: 26 March 2021 Accepted: 2 August 2021

Published online: 16 August 2021

\section{References}

1. Jackson DC. Flathead catfish: biology, fisheries, and management. In: Catfish 2000: proceedings of the international ictalurid symposium. Bethesda: American Fisheries Society, 23-35. Symposium vol. 24.

2. Kwak TJ, Waters DS, Pine WE III. Age, growth, and mortality of introduced flathead catfish in Atlantic rivers and a review of other populations. N Am J Fish Manage. 2006;26(1):73-87.

3. Bringolf RB, Kwak TJ, Cope WG, Larimore MS. Salinity tolerance of flathead catfish: implications for dispersal of introduced populations. Trans Am Fish Soc. 2005;134(4):927-36.

4. Guier CR, Nichols LE, Rachels RT. Biological investigation of flathead catfish in the Cape Fear River. In: Proceedings of the annual conference southeastern association of fish and wildlife agencies. vol. 35, No. 1981; 1984. p. 607-21.

5. Bonvechio TF, Marsik JE, Bussells CW. Population dynamics of introduced Flathead Catfish in two Atlantic coastal plain rivers under differing management strategies. J Southeastern Assoc Fish Wildl Agencies. 2016:3:128-35.

6. Schmitt JD, Emmel JA, Bunch AJ, Hilling CD, Orth DJ. Feeding ecology and distribution of an invasive apex predator: flathead catfish in subestuaries of the Chesapeake Bay, Virginia. N Am J Fish Manage. 2019;39(2):390-402.

7. Pine WE III, KwakTJ, Rice JA. Modeling management scenarios and the effects of an introduced apex predator on a coastal riverine fish community. Trans Am Fish Soc. 2007;136(1):105-20.

8. Fuller PL, Nico LG, Williams JD. Nonindigenous fishes introduced into the inland waters of the United States. American Fisheries Society, Special Publication 2000;27, Bethesda, Maryland.

9. Bonvechio TF, Allen MS, Gwinn D, Mitchell JS. Impacts of electrofishing removals on the introduced flathead catfish population in the Satilla River, Georgia. In: American fisheries society symposium 2011, vol. 77. p. 395-407.

10. Liu Z, Tan G, Kucuktas H, Li P, Karsi A, Yant DR, Dunham RA. Brief communication. High levels of conservation at microsatellite loci among ictalurid catfishes. J Hered. 1999;90(2):307-12.

11. Waldbieser GC, Bosworth BG. A standardized microsatellite marker panel for parentage and kinship analyses in channel catfish Ictalurus punctatus. Anim Genet. 2013;44(4):476-9.

12. Waldbieser GC, Wolters WR. Application of polymorphic microsatellite loci in a channel catfish /ctalurus punctatus breeding program. J World Aquacult Soc. 1999;30(2):256-62.
13. Waldbieser GC, Wolters WR. Definition of the USDA103 strain of channel catfish (Ictalurus punctatus). Anim Genet. 2007;38(2):180-3.

14. Tan G, Karsi A, Li P, Kim S, Zheng X, Kucuktas H, Argue BJ, Dunham RA, Liu ZJ. Polymorphic microsatellite markers in /ctalurus punctatus and related catfish species. Mol Ecol. 1999;8(10):1758-60.

15. Boutin-Ganache I, Raposo M, Raymond M, Deschepper CF. M13-tailed primers improve the readability and usability of microsatellite analyses performed with two different allele sizing methods. Biotechniques. 2001;31(1):24-8.

16. Aunins AW, Eackles MS, Kazyak DC, Drummond MR, King TL. Development of microsatellite markers for three at risk tiger beetles Cicindela dorsalis dorsalis, C. d. media, and C. puritana. BMC Res Notes. 2020;13(171):1-10.

17. Holleley CE, Geerts PG. Multiplex Manager 1.0: a cross-platform computer program that plans and optimizes multiplex PCR. Biotechniques. 2009;46(7):511-7.

18. Van Oosterhout C, Hutchinson WF, Wills DPM, Shipley P. MICRO-CHECKER: software for identifying and correcting genotyping errors in microsatellite data. Mol Ecol Notes. 2004;4(3):535-8.

19. Rousset F. genepop'007: a complete re-implementation of the Genepop software for Windows and Linux. Mol Ecol Resour. 2008;8(1):103-6.

20. Peakall R, Smouse PE. GENALEX 6: genetic analysis in Excel. Population genetic software for teaching and research. Mol Ecol Notes. 2006:6:288-95

21. Peakall R, Souse PE. Population genetic software for teaching and research-an update. Bioinformatics. 2012;28:2537-9.

22. Kalinowski ST. Hp-rare 1.0: a computer program for performing rarefaction on measures of allelic richness. Mol Ecol Notes. 2005;5(1):187-9.

23. Pritchard JK, Stephens M, Donnelly P. Inference of population structure using multilocus genotype data. Genetics. 2000;155:945-59.

24. Li YL, Liu JX. StructureSelector: a web-based software to select and visualize the optimal number of clusters using multiple methods. Mol Ecol Resour. 2018;18(1):176-7.

25. Evanno G, Regnaut S, Goudet J. Detecting the number of clusters of individuals using the software structure: a simulation study. Mol Ecol. 2005;14(8):2611-20.

26. Brown JJ, Perillo J, Kwak TJ, Horwitz RJ. Implications of Pylodictis olivaris (flathead catfish) introduction into the Delaware and Susquehanna drainages. Northeast Nat. 2005;12(4):473-84.

27. Smith GD, Massie DL, Perillo J, Wagner T, Pierce D. Range expansion and factors affecting abundance of invasive flathead catfish in the Delaware and Susquehanna rivers, Pennsylvania, USA. N Am J Fish Manag; 2021

28. White SL, Hanks EM, Wagner T. A novel quantitative framework for riverscape genetics. Ecol Appl. 2020;30(7):e02147.

\section{Publisher's Note}

Springer Nature remains neutral with regard to jurisdictional claims in published maps and institutional affiliations.

Ready to submit your research? Choose BMC and benefit from:

- fast, convenient online submission

- thorough peer review by experienced researchers in your field

- rapid publication on acceptance

- support for research data, including large and complex data types

- gold Open Access which fosters wider collaboration and increased citations

- maximum visibility for your research: over 100M website views per year

At BMC, research is always in progress.

Learn more biomedcentral.com/submissions 